\title{
Doxorubicin Enhances the Expression of Transgene Under Control of the CMV Promoter in Anaplastic Thyroid Carcinoma Cells
}

\author{
Kwang Il Kim ${ }^{1-4}$, Joo Hyun Kang ${ }^{1,4}$, June-Key Chung ${ }^{1-4}$, Yong Jin Lee ${ }^{1-4}$, Jae Min Jeong ${ }^{1,4}$, Dong Soo Lee ${ }^{1,4}$, and \\ Myung Chul Lee ${ }^{1}$ \\ ${ }^{I}$ Department of Nuclear Medicine, Seoul National University College of Medicine, Seoul, Korea; ${ }^{2}$ Institute of Radiation Medicine, \\ Seoul National University College of Medicine, Seoul, Korea; ${ }^{3}$ Tumor Immunity Medical Research Center, Seoul National University \\ College of Medicine, Seoul, Korea; and ${ }^{4}$ Cancer Research Institute, Seoul National University College of Medicine, Seoul, Korea
}

We investigated the effect of doxorubicin on transgene expression and evaluated the mechanism of enhanced transgene expression by doxorubicin in transfected human anaplastic thyroid cancer cells (ARO cells). Methods: ARO cells were transfected with plasmid vectors or adenoviral vectors expressing human sodium/iodide symporter (hNIS) or luciferase (Luc) under the control of cytomegalovirus (CMV) promoter. After treating transfected and control ARO cells with doxorubicin, iodide uptake assay and luciferase assay were performed. Reversedphase polymerase chain reaction analysis for hNIS and Western blot analysis for IкB protein were executed. Electrophoretic mobility-shift assay (EMSA) was performed to evaluate nuclear

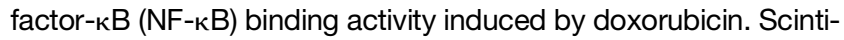
graphic and bioluminescent images were acquired and quantitated before and after doxorubicin in a tumor-bearing mouse model. Results: Radioiodide uptake in ARO cells transfected with the NIS gene under the CMV promoter was remarkably enhanced by doxorubicin, and this corresponded to a significant increase in NIS messenger RNA. In addition, luciferase gene upregulation by doxorubicin was also observed in luciferase gene transfected ARO cells. These results were verified by in vivo imaging in a tumorbearing mouse model. Moreover, transgene expressional enhancement by doxorubicin was observed after transfecting ARO cells with adenoviral vector or plasmid vector, when transgenes were under the control of a CMV promoter. In addition, NF-kB, activated by doxorubicin, induced transgene transcription under the control of the CMV promoter, which possesses an NF- $\mathrm{BB}$ binding site. Conclusion: These findings indicate that doxorubicin enhances transgene expression under the control of the CMV promoter and that doxorubicin might be used as an adjuvant to radioiodine therapy by NIS gene transfer in anaplastic thyroid carcinoma.

Key Words: anaplastic thyroid cancer; doxorubicin; transgene; imaging reporter gene; gene therapy

J Nucl Med 2007; 48:1553-1561

DOI: 10.2967/jnumed.106.038612

\footnotetext{
Received Dec. 6, 2006; revision accepted May, 16, 2007.

For correspondence or reprints contact: June-Key Chung, MD, PhD, Department of Nuclear Medicine, Seoul National University Hospital, 28, Yongon-dong, Jongno-gu, Seoul 110-744, Korea.

E-mail: jkchung@plaza.snu.ac.kr

COPYRIGHT @ 2007 by the Society of Nuclear Medicine, Inc.
}

N everal investigations, including preclinical studies and clinical trials, have generated promising results in the cancer gene therapy field. Therapeutic genes, such as herpes simplex virus type 1 thymidine kinase (HSV1-tk) and cytosine deaminase, have been widely used for molecular prodrug therapy in cancer (1-3), and radiotargeted gene therapy aimed at localizing radionuclides at tumor sites has also been demonstrated to have potential (4).

Sodium/iodide symporter (NIS) is a specific transporter that cotransports sodium and an iodide ion. The targeted expression of NIS in cancer cells allows these cells to concentrate iodide from plasma, and several radiotargeted gene therapy studies using NIS gene transfer into various cancer cells and tumor xenografts have achieved encouraging results (5-7). In addition, the recently cloned and characterized human NIS (hNIS) gene has attracted attention because of its strong iodide transport activity, nonimmunoreactivity, and proven efficiency in the radioiodine therapy of thyroid cancer $(8-10)$. However, despite the successes of these investigations, improved gene expression strategies are needed to enhance the efficacies of gene therapies.

Previously, we transferred the NIS gene under cytomegalovirus (CMV) promoter into human anaplastic thyroid cancer cells (ARO cells) for radioiodine therapy and therapeutic intervention imaging (11). However, several problems remain, such as rapid washout of radionuclide from cells and its limited retention within cells (9). Thus, new strategies are needed to enhance radionuclide accumulation or retain radioiodine in cells. Here, we report that radioiodide uptake was remarkably enhanced when doxorubicin was administered to hNIS gene-transfected ARO cells. Genotoxic stresses, such as those induced by irradiation and chemotherapy, are known to enhance transgene expression, including NF- $\kappa \mathrm{B}$ activation, in cancer cells $(12,13)$, and it has been reported that CMV promoter, a strong viral promoter, has consensus binding sites for NF-кB in its enhancer region (14). 
In this study, transgene expression under the control of a CMV promoter was enhanced in ARO cells in vitro and in a mouse model by doxorubicin. This enhancement was mediated by the activation of NF- $\mathrm{BB}$ in the CMV promoter. Overall, our results provide a useful strategy for radioiodine therapy by NIS gene transfer in anaplastic thyroid carcinoma and a means for improving therapeutic gene expression in other gene therapy applications.

\section{MATERIALS AND METHODS}

\section{Plasmid Vectors and Viruses}

pCMV-NIS and pCMV-Luc plasmids containing human NIS (hNIS) and luciferase, respectively, were made by inserting hNIS or luciferase into pCDNA3.1 (Invitrogen). The hNIS gene was released from a plasmid kindly provided by Dr. Sissy M. Jhiang (Ohio State University, Columbus, OH), as described previously (15), except that we used Xho I and Xba I restriction enzymes. Luciferase was cloned from pGL2 vector (Promega) using the same method as that used for hNIS, but using the following primers-forward primer 5'-CCGGAAGCTTATGGAAGACGCCAAAAACAT-3' and reverse primer 5'-CCGGCTCGAGTTACAATTTGGACTTTCCGC- $3^{\prime}$ - and the restriction enzymes HindIII and Xho I.

Adenoviruses expressing hNIS (Ad-hNIS) or luciferase (AdLuc) under the control of the CMV promoter were made by recombining hNIS containing shuttle vector or luciferase containing shuttle vector with adenoviral backbone, respectively, using the AdEasy Adenoviral Vector System, following the manufacturer's instructions (Qbiogene). Viruses were amplified in 293 cells, purified by $\mathrm{CsCl}$ gradient ultracentrifugation, and then titered using the median tissue culture infective dose $\left(\mathrm{TCID}_{50}\right)$ according to standard protocols. Viral stocks were maintained at $-70^{\circ} \mathrm{C}$ for long-term storage.

\section{Cell Culture and Vector Transfer}

Human anaplastic thyroid cancer cells, ARO cells, were grown in RPMI-1640 medium containing 100,000 IU/L penicillin, 100 $\mu \mathrm{g} / \mathrm{mL}$ streptomycin, $250 \mu \mathrm{g} / \mathrm{L}$ amphotericin B, and $10 \%(\mathrm{v} / \mathrm{v})$ fetal bovine serum (Invitrogen) in a humidified 5\% $\mathrm{CO}_{2} / 95 \%$ air atmosphere at $37^{\circ} \mathrm{C}$. Cell viability was evaluated by trypan blue exclusion.

ARO cells were transfected with pCMV-NIS or pCMV-Luc vector using Lipofectamine PLUS reagent, according to the manufacturer's instructions (Invitrogen). Selection was performed using 300-800 $\mu \mathrm{g} / \mathrm{mL}$ geneticin (Invitrogen) in RPMI-1640 medium containing $10 \%$ fetal bovine serum for $2 \mathrm{wk}$, beginning the day after transfection. Surviving clones (ARO-hNIS and ARO-Luc) were isolated and screened for iodide uptake activity and bioluminescence.

In addition, ARO cells were transduced at a multiplicity of infection of 0.1 plaque-forming unit (pfu) with Ad-hNIS and AdLuc, respectively. Vector was then removed by washing, and cells were further cultured for $24 \mathrm{~h}$ before being analyzed for transgene expression.

\section{Treatments with Doxorubicin or NF-кB Pathway Inhibitor}

Transduced and control ARO cells were inoculated in quadruplicate into 24 -well plates at $3 \times 10^{5}$ cells per well. After incubation for $12 \mathrm{~h}$, each well was washed with phosphate-buffered saline (PBS), and medium was replaced with fresh medium containing doxorubicin at $1,2,3,4,5,6,7,8,9,10$, or $15 \mu \mathrm{g} /$ $\mathrm{mL}$. The cells were then incubated in $5 \% \mathrm{CO}_{2}$ for $24 \mathrm{~h}$ at $37^{\circ} \mathrm{C}$. For NF-кB pathway inhibition assays, cells were pretreated with the inhibitory к B kinase (IKK) inhibitor $10 \mu \mathrm{M}$ Bay 11-7082 (Alexis), for $1 \mathrm{~h}$, and then incubated in the presence of doxorubicin.

\section{I Uptake Assays}

ARO cells stably transfected with reporter vector (ARO-hNIS) were plated at $3 \times 10^{5}$ cells per well in a 24-well plate and then cultured for $12 \mathrm{~h}$ with RPMI-1640 medium containing $10 \%$ fetal bovine serum. The cells were then treated with doxorubicin, and $24 \mathrm{~h}$ later clones were assessed for NIS activity by measuring radioiodide uptake at $37^{\circ} \mathrm{C}$ using a previously described method (15). In brief, iodide uptake levels were determined by incubating cells with $500 \mu \mathrm{L}$ Hanks' balanced salt solution (HBSS) containing $0.5 \%$ bovine serum albumin (BSA) and $10 \mathrm{mM}$ 2-[4-(2hydroxyethyl)-1-piperazinyl] ethanesulfonic acid/ $\mathrm{NaOH}$ ( $\mathrm{pH} 7.4)$, $3.7 \mathrm{kBq}$ of carrier-free $\mathrm{Na}^{125} \mathrm{I}$, and $10 \mu \mathrm{M} \mathrm{NaI}$, to yield a specific activity of $740 \mathrm{MBq} / \mathrm{mmol}$ at $37^{\circ} \mathrm{C}$ over $30 \mathrm{~min}$. After incubation, cells were washed twice, as quickly as possible $(<15 \mathrm{~s})$, with $2 \mathrm{~mL}$ of iodine-free ice-cold HBSS buffer, detached with $500 \mu \mathrm{L}$ trypsin, and then measured for radioactivity using a $\gamma$-counter (Cobra II; Canberra Packard).

\section{Luciferase Assays}

Transfected and control ARO cells were inoculated into 24-well plates at $3 \times 10^{5}$ cells per well. After incubation for $12 \mathrm{~h}$, wells were washed with PBS, medium was replaced with fresh medium containing various concentrations of doxorubicin, and cells were incubated in $5 \% \mathrm{CO}_{2}$ for $24 \mathrm{~h}$ at $37^{\circ} \mathrm{C}$. Bioluminescence assays were performed using Luciferase Assay Kits (Applied Biosystems). Lysis solution was added to each well, and cell lysates were transferred to microplates. Bioluminescence was measured using a TR717 microplate luminometer (Applied Biosystems).

For in vitro bioluminescent imaging, after adding a mixture of luciferin and buffer solution, microplates were placed in a dark box of the LAS-3000 luminescent image analyzer (Fuji Film), and images were acquired over $2 \mathrm{~min}$. Acquired bioluminescent images were quantified using the Multi Gauge, version 3.02, image analysis program (Fuji Film), which determined the optical densities (ODs) of regions of interest (ROIs) on the images.

\section{Reverse Transcriptase Polymerase Chain Rreaction (RT-PCR) Analysis for hNIS}

Total RNA was prepared from ARO-NIS cells using TRIZOL reagent (Invitrogen) according to the manufacturer's instructions, with slight modification. Briefly, approximately $500 \mathrm{ng}$ of total RNA were reverse-transcribed in a final volume of $20 \mu \mathrm{L}$ containing $1 \mu \mathrm{L}$ oligo(dT), $4 \mu \mathrm{L} 5 \times$ first-strand buffer, $2 \mu \mathrm{L} 0.1 \mathrm{M}$ dithiothreitol (DTT), $1 \mu \mathrm{L} 10 \mathrm{mM}$ deoxyribonucleoside triphosphate (dNTP) mix, and Moloney Murine Leukemia Virus (MMLV) reverse transcriptase (Invitrogen). PCR was performed in a total volume of $20 \mu \mathrm{L}$ containing $2 \mu \mathrm{L}$ of complementary DNA, $2 \mu \mathrm{L}$ of $10 \times$ reaction buffer, forward primer ( $5^{\prime}$-TCTCTCAGTCAACGCCTCT$\left.3^{\prime}\right)$ and reverse primer (5'-ATCCAGGATGGCCACTTCTT-3'), $1 \mu \mathrm{L}$ of $10 \mathrm{mM}$ dNTP, and 2.5 units of Taq-DNA polymerase (GeneCraft) using a GeneAmp PCR System (Applied Biosystems). Samples were subjected to $5 \mathrm{~min}$ of denaturation at $94^{\circ} \mathrm{C}, 25$ amplification cycles $\left(30 \mathrm{~s}\right.$ at $94^{\circ} \mathrm{C}, 30 \mathrm{~s}$ at $47^{\circ} \mathrm{C}$, and $1 \mathrm{~min}$ at $\left.72^{\circ} \mathrm{C}\right)$, and an additional $5 \mathrm{~min}$ at $72^{\circ} \mathrm{C}$. 
$\beta$-Actin was amplified as a control using the same reaction conditions but with $\beta$-actin primers, forward ( $5^{\prime}$-TGACGGGGTCACCCACACTGTGCCCATCTA-3') and reverse (5'-CTAGAAGCATTTGCGGTGGACGATGGAGGG-3'). Samples were subjected to $5 \mathrm{~min}$ of denaturation at $94^{\circ} \mathrm{C}, 23$ amplification cycles $\left(30 \mathrm{~s}\right.$ at $94^{\circ} \mathrm{C}, 30 \mathrm{~s}$ at $50^{\circ} \mathrm{C}$, and $1 \mathrm{~min}$ at $72^{\circ} \mathrm{C}$ ), and an additional $5 \mathrm{~min}$ at $72^{\circ} \mathrm{C}$. Amplified products were analyzed by ethidium bromide-stained agarose gel electrophoresis. Results were interpreted using Tina 2.1 software (Raytest). Expression values of the NIS gene were calculated by dividing NIS band intensities by those of $\beta$-actin. The correlation between gene expression (by RT-PCR) and protein activity (by radioiodide uptake) was analyzed using Sigma Plot 2001 (SPSS Inc.).

\section{Western Blot Analysis}

For the immunodetection of I $\mathrm{B} \alpha \alpha$, ARO-hNIS cells were incubated with $0,1,2,3,4$, or $5 \mu \mathrm{g} / \mathrm{mL}$ of doxorubicin for $24 \mathrm{~h}$, and cytoplasmic extracts were then prepared. Cells were harvested with a scraper after being washed with ice-cold PBS and lysed in a buffer containing $10 \mathrm{mM}$ Tris $\cdot \mathrm{HCl}(\mathrm{pH}$ 7.5), $1 \mathrm{mM} \mathrm{DTT,} 20 \%$ (v/v) glycerol, $1 \mathrm{mM}$ ethylenediaminetetraacetic acid (EDTA), and a protease inhibitor mixture. Samples were then centrifuged at $4^{\circ} \mathrm{C}$ for $5 \mathrm{~min}$, and supernatants were mixed with $\mathrm{NaDodSO}_{4}$ sample buffer (1:2), and boiled for $5 \mathrm{~min}$. Samples $(10 \mu \mathrm{L})$ of these mixtures were electrophoresed in bis-Tris. $\mathrm{HCl}$ buffered $4 \%-$ $12 \%$ gradient polyacrylamide gels (Invitrogen). After transferring proteins to nitrocellulose membranes (Schleicher \& Schuell Inc.) by electroblotting, membranes were incubated in 3\% skim milk in TBS-T (20 mM Tris, $137 \mathrm{mM} \mathrm{NaCl}$, and $0.1 \%$ Tween 20 ), and then treated with antibodies against $\mathrm{I} \kappa \mathrm{B} \alpha$ (sc-371; dilution, 1:1,000; Santa Cruz Biotechnology), and $\alpha$-tubulin (clone B-5-12; dilution, 1:2,000; Sigma). These proteins were located using enhanced chemiluminescence (ECL) reagents (Roche). Protein concentrations in samples were assayed using BCA Protein Assay kits (Pierce).

\section{Electrophoretic Mobility-Shift Assays (EMSA)}

Nuclear extracts were prepared from doxorubicin-nontreated and -treated (at $3 \mu \mathrm{g} / \mathrm{mL}$ ) ARO-hNIS cells using NE-PER Nuclear and Cytoplasmic Extraction Reagents kits, according to the manufacturer's instructions (Pierce). Gel-shift assays were performed using EMSA kits (Panomics). For the binding reaction, $5 \mu \mathrm{g}$ of nuclear extracts were incubated at room temperature for $30 \mathrm{~min}$ with reaction buffer containing; $20 \mathrm{mM} N$-(2-hydroxyethyl)piperazine- $N^{\prime}$-(2-ethanesulfonic acid) at $\mathrm{pH} 7.9,50 \mathrm{mM} \mathrm{KCl}, 0.1 \mathrm{mM}$ EDTA, $1 \mathrm{mM}$ DTT, 5\% glycerol, $200 \mu \mathrm{g} / \mathrm{mL}$ BSA, $2 \mu \mathrm{g}$ of poly(dI$\mathrm{dC})$, and the biotin-labeled probes $(10 \mathrm{ng})$, containing the NF- $\mathrm{BB}$ binding consensus sequence (5'-AGTTGAGGGGACTTTCCCAGGC-3'). The negative control contained free probe (without nuclear extract).

To further prove binding specificity, a competition experiment was performed with an unlabeled oligonucleotide containing the $\mathrm{NF}-\kappa \mathrm{B}$ binding site of the CMV promoter. As a competition control, excess unlabeled cold probes were added to samples containing nuclear extract and biotin-labeled probe. Samples were separated in $6 \%$ polyacrylamide gels in $0.5 \%$ Tris-borate-EDTA (TBE) and transferred onto nylon membranes, which were fixed by ultraviolet-induced cross-linking. The biotin-labeled probe was detected using streptavidin/horseradish peroxidase (Panomics).

\section{Animal Experiments}

All animal experiments were performed with the approval of the Seoul National University Animal Research Committee. Tumor xenografts were produced in male BALB/c nude mice, 6-wkold, by subcutaneously injecting $5 \times 10^{6}$ ARO cells suspended in $100 \mu \mathrm{L}$ of serum-free RPMI-1640 medium into both left and right hind flanks. After allowing $2 \mathrm{wk}$ for tumor growth, when the diameter of tumors reached a minimum size of $7 \mathrm{~mm}$, adenoviruses were injected. PBS and Ad-hNIS $\left(1 \times 10^{7} \mathrm{pfu}\right)$ were injected into tumor masses in the left and right thighs, respectively. For bioluminescent imaging, Ad-Luc $\left(1 \times 10^{7} \mathrm{pfu}\right)$ was injected instead of Ad-hNIS. Because the adenoviral vector is not designed for cancer cell-specific infection, the vector was injected intratumorally.

On day 2 after adenovirus injection, scintigraphic and bioluminescent images were acquired. Anesthesia was performed by intraperitoneally injecting ketamine $(53 \mathrm{mg} / \mathrm{kg})$ and xylazine $(12$ $\mathrm{mg} / \mathrm{kg}$ ) solution $10 \mathrm{~min}$ before imaging.

To obtain scintigraphic images, $30 \mathrm{~min}$ after injecting 18.5 $\mathrm{MBq}$ of ${ }^{99 \mathrm{~m}} \mathrm{Tc}$-pertechnetate intraperitoneally per animal, mice were placed in a spread prone position and scanned with an $\mathrm{ON}$ $410 \gamma$-camera (Ohio Nuclear) equipped with a pinhole collimator. Chen et al. (16) demonstrated that treatment effects were not dependent on the administration route (intraperitoneal and intravenous). We chose the intraperitoneal injection method, which is more easily performed and reproducible than the intravenous injection method. To estimate tumor dosimetry and to confirm scintigraphic measurements, individual tumors and muscle were sampled, weighed, and assayed for ${ }^{99 \mathrm{~m}} \mathrm{Tc}$-pertechnetate radioactivity using a $\gamma$-counter (Cobra II; Canberra Packard). To normalize data to body background activity, tumor-to-muscle radioactivity ratios were calculated.

For bioluminescent imaging, an aqueous solution of luciferin (5 mg/mouse; Molecular Probes) was injected intraperitoneally over $10 \mathrm{~min}$, and then the animal was placed in an LAS-3000 dark box (Fuji Film). After obtaining gray-scale images under white light, bioluminescent images were acquired by collecting and integrating light for $10 \mathrm{~min}$. Image processing and analysis were performed as described earlier. Acquired bioluminescent images were quantified using the Multi Gauge, version 3.02 image analysis program (Fuji Film), which determined the ODs of ROIs on images.

One day after a $0.2-\mathrm{mL}$ intraperitoneal injection of $3.2 \mathrm{mg} / \mathrm{kg}$ doxorubicin, scintigraphic and bioluminescent images were also obtained as described.

\section{Statistical Analysis}

Results are expressed as mean $\pm \mathrm{SD}$. The unpaired $t$ test was used to determine the statistical significance for all comparisons. $P$ values $<0.05$ were considered statistically significant.

\section{RESULTS}

\section{Increased Transgene Expression by Doxorubicin in hNIS or Luc Gene-Transfected ARO Cells}

Doxorubicin-treated ARO-hNIS cells showed increased iodide uptake without loss of cell viability (Fig. 1A). When these cells were treated with doxorubicin at concentrations from 1 to $15 \mu \mathrm{g} / \mathrm{mL}$ for $24 \mathrm{~h}$, iodide uptake increased significantly by up to 21.9-fold in a dose-dependent manner 


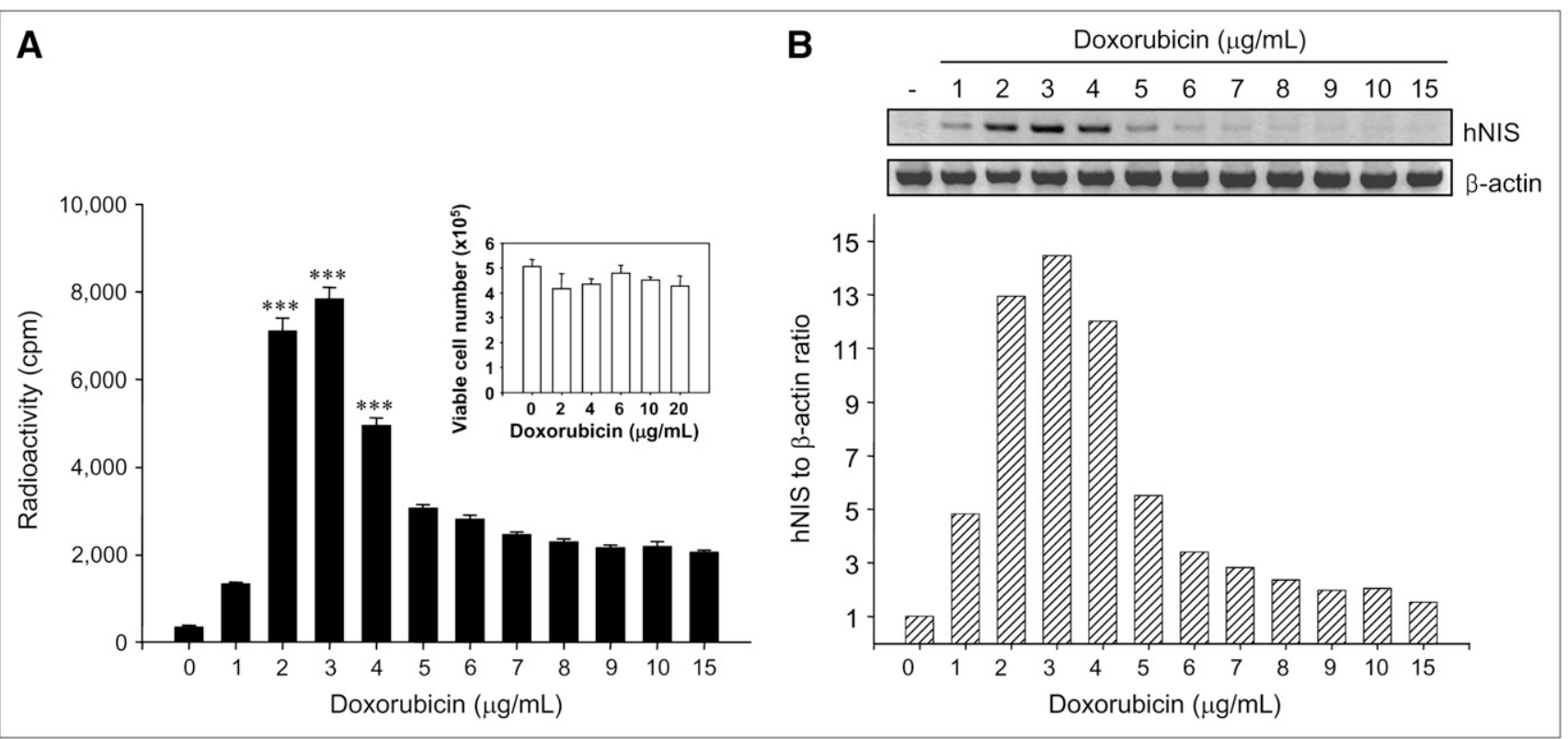

FIGURE 1. (A) Relation between ${ }^{125}$ uptake and doxorubicin concentration in ARO-hNIS cells. (Inset) Viable cell numbers among doxorubicin-treated ARO-hNIS cells. lodide uptake was measured by incubating cells for 30 min with $3.7 \mathrm{kBq}$ of ${ }^{125}$ in $\mathrm{HBSS}, 24 \mathrm{~h}$ after doxorubicin treatment. For ARO-hNIS cells, increased iodide uptake was observed in doxorubicin-treated cells without loss of cell viability. Results are presented as mean \pm SD of 4 independent experiments performed in quadruplicate ${ }^{* * \star} P<0.001$ vs. nontreated cells). (B) RT-PCR analysis of hNIS gene expression at different doxorubicin concentrations in ARO-hNIS cells. hNIS mRNA levels were significantly increased by doxorubicin treatment, and this peaked (14.5-fold) at a doxorubicin concentration of $3 \mu \mathrm{g} / \mathrm{mL}$. Moreover, these levels corresponded with iodide uptake under the same conditions.

until the doxorubicin concentration reached $3 \mu \mathrm{g} / \mathrm{mL}$ (Fig. 1A). However, incubation with higher concentrations resulted in reduced iodide uptake (13.9-fold for $4 \mu \mathrm{g} / \mathrm{mL}$ and 5.8-fold for $15 \mu \mathrm{g} / \mathrm{mL}$ ). RT-PCR analysis also revealed that hNIS mRNA levels were significantly increased and that this also peaked at 14.5 -fold at $3 \mu \mathrm{g} / \mathrm{mL}$ ( 12 -fold at $4 \mu \mathrm{g} / \mathrm{mL}$ and 1.6-fold at $15 \mu \mathrm{g} / \mathrm{mL}$ ), which corresponded with iodide uptake (Fig. 1B). Moreover, a good correlation $\left(r^{2}=0.88\right)$ was found between ${ }^{125} \mathrm{I}$ uptake and hNIS gene expression in this in vitro model.

To determine whether iodide uptake increase by doxorubicin in ARO-hNIS cells was due to the reactivation of the epigenetically silenced endogenous gene, we investigated whether doxorubicin induced NIS gene reactivation in ARO cells. However, no significant increase in radioiodine accumulation was observed in ARO cells after doxorubicin treatment.

When ARO-Luc cells were treated with doxorubicin, bioluminescence increased markedly in the same manner as that observed in ARO-hNIS cells (Fig. 2). At $3 \mu \mathrm{g} / \mathrm{mL}$, bioluminescence was maximal at 13.3-fold; further increases in doxorubicin reduced bioluminescence (5.2-fold at $4 \mu \mathrm{g} / \mathrm{mL}$ and 1.4 -fold at $5 \mu \mathrm{g} / \mathrm{mL}$ ).

To explain why radioactivity and bioluminescence showed the peak at $3 \mu \mathrm{g} / \mathrm{mL}$ of doxorubicin, we performed a cell cycle analysis and compared this with the doxorubicin concentration. Transient $\mathrm{G}_{2} / \mathrm{M}$ arrest occurred up to $2 \mu \mathrm{g} / \mathrm{mL}$, and $\mathrm{G}_{1}$ arrest progressed with concentrations of $3 \mu \mathrm{g} / \mathrm{mL}$ or higher (data not shown). In addition, no apoptotic fraction was observed in all samples.

\section{Induction of Transgene Expression by Doxorubicin in ARO Cells Transduced with Adenoviral Vectors}

We also analyzed whether transgene expression by adenoviral vector was induced by doxorubicin. A dramatic increase in iodide uptake and bioluminescence was observed after administering doxorubicin to transduced ARO cells, where hNIS and Luc genes were under the control of the CMV promoter in adenoviral vector (Figs. 3 and 4). When Ad-hNIS-transduced ARO cells were treated with doxorubicin for $24 \mathrm{~h}$, iodide uptake levels significantly increased (3.7-fold at $3 \mu \mathrm{g} / \mathrm{mL}$ ) (Fig. 3). Ad-Luc-transduced ARO cells also showed peak (24.5-fold) luciferase activity at a doxorubicin concentration of $3 \mu \mathrm{g} / \mathrm{mL}$ (Fig. 4).

\section{Influence of NF-кB Activity on CMV Promoter}

To examine whether the degradation of IкB $\alpha$ participates in the effect of doxorubicin on enhancement of transgene expression, ІкВ $\alpha$ protein expression was detected by Western blotting using an anti-IкB $\alpha$ antibody. When the cytoplasmic extracts of ARO-hNIS cells treated with $0,1,2,3$, 4 , or $5 \mu \mathrm{g} / \mathrm{mL}$ of doxorubicin were examined, significant dose-dependent reductions in immunoreactive $\mathrm{I} \kappa \mathrm{B} \alpha$ protein levels were observed (Fig. 5A).

In addition, EMSA revealed an increase in NF- $\mathrm{B}$ binding to biotin-labeled oligonucleotide after $24 \mathrm{~h}$ of doxorubicin treatment (Fig. 5B). Competition with unlabeled oligonucleotide containing the NF- $\mathrm{KB}$ binding site of the $\mathrm{CMV}$ promoter resulted in a significant reduction in NF- $\mathrm{KB}$ 


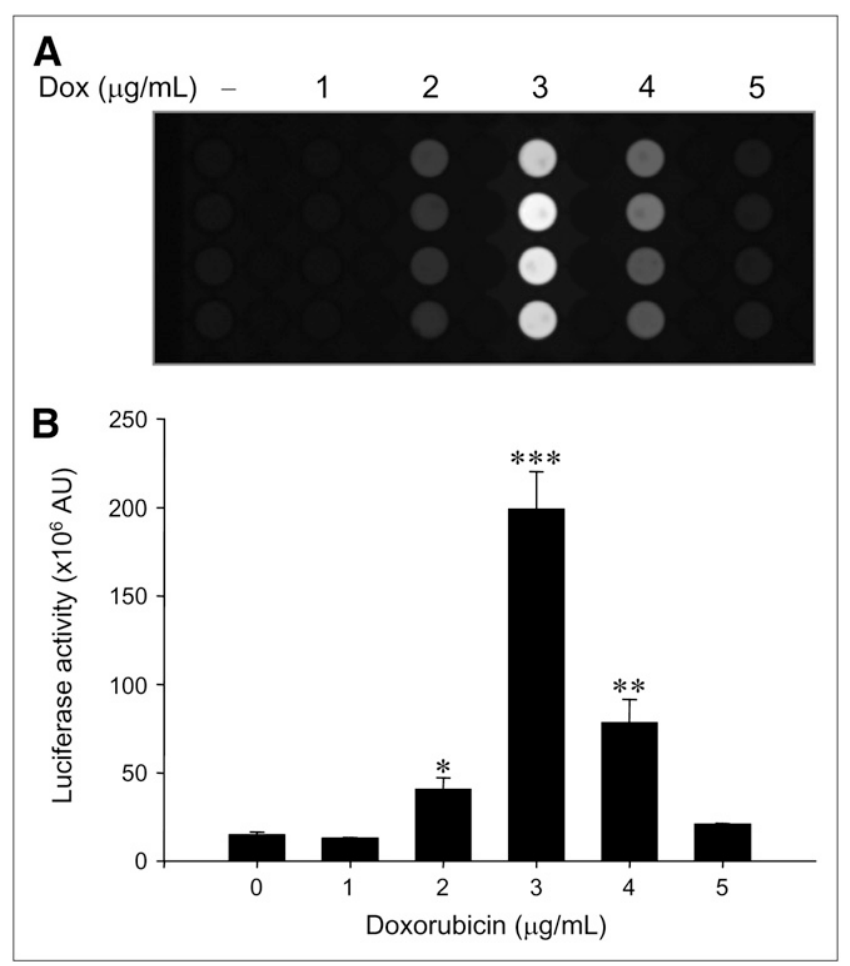

FIGURE 2. Relation between bioluminescence and doxorubicin concentration in ARO-Luc cells. (A) In vitro bioluminescent images dependent on doxorubicin (Dox) concentrations in ARO-Luc cells. Bioluminescent images were acquired using an LAS-3000 imaging analyzer equipped with a cooled chargecoupled device camera. (B) Dose-dependent upregulation of bioluminescence by doxorubicin in ARO-Luc cells. Acquired bioluminescent images were quantified by image analysis (Multi Gauge, version 3.02), which measured ODs in ROls. Luciferase activities were maximal at a doxorubicin concentration of $3 \mu \mathrm{g} / \mathrm{mL}$, and further increases in doxorubicin reduced bioluminescence. Results are expressed as mean $\pm S D$ of experiments performed in quadruplicate $\left({ }^{\star} P<0.05\right.$; ${ }^{\star \star} P<0.005$; ${ }^{\star \star \star} P<0.001$ vs. nontreated cells). AU = arbitrary units.

binding. However, biotin-labeled oligonucleotide without nuclear extracts showed no specific binding activity for NF-кB.

We also pretreated transduced ARO cells with the IKK inhibitor (Bay 11-7082) before adding doxorubicin and then examined whether the enhancement of transgene expression by doxorubicin was selectively targeted for the activation of the NF- $\mathrm{BB}$ pathway. Treatment with doxorubicin resulted in an increase in iodide uptake or bioluminescence in Ad-hNIS- or Ad-Luc-infected ARO cells, respectively. Moreover, as expected, treatment with the IKK inhibitor markedly inhibited the induction of transgene expression by doxorubicin (Fig. 6; ${ }^{* *} P<0.005$ vs. doxorubicin-treated cells infected with Ad-hNIS or Ad-Luc).

\section{In Vivo Monitoring of Enhanced Transgene Expression by Doxorubicin Using Scintigraphic and Bioluminescent Imaging}

Neither radioactivity nor bioluminescence was observed in tumor masses treated with PBS (left thigh). Injection with Ad-hNIS or Ad-Luc caused ${ }^{99 \mathrm{~m}} \mathrm{Tc}$-pertechnetate up-

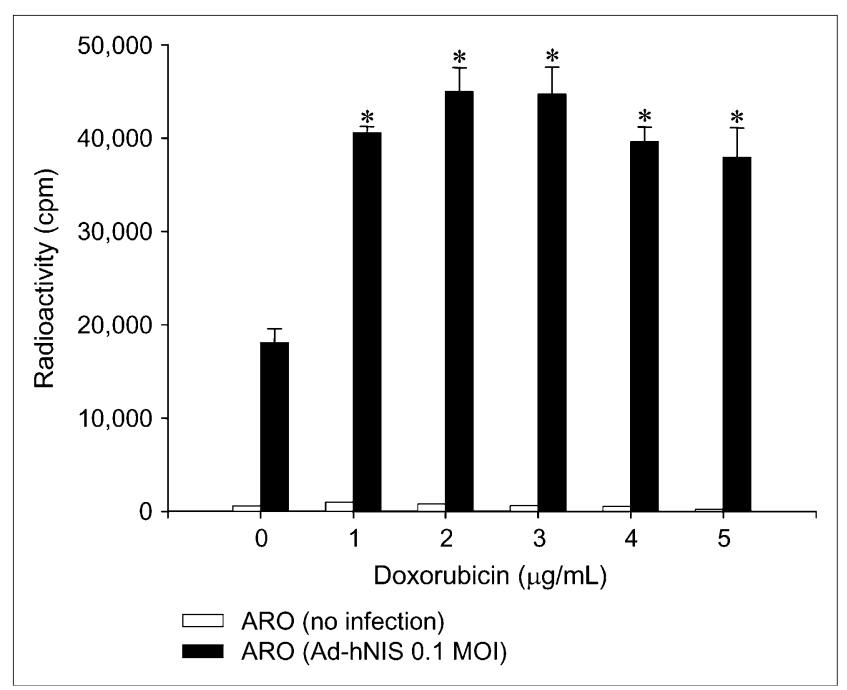

FIGURE 3. Dose-dependent upregulation of ${ }^{125}$ l uptake by doxorubicin in Ad-hNIS-transduced ARO cells. When AdhNIS-transduced ARO cells were treated with doxorubicin for $24 \mathrm{~h}$, iodide uptake levels significantly increased and peaked at a doxorubicin concentration of $3 \mu \mathrm{g} / \mathrm{mL}$. Results are the mean \pm $\mathrm{SD}$ of 2 independent experiments performed in quadruplicate ( ${ }^{\star} P<0.05$ vs. nontreated cells infected with Ad-hNIS). MOI = multiplicity of infection.

take or bioluminescence, respectively, to some measure in tumor masses. However, as shown in Figures 7A and 7C, significantly enhanced reporter gene activity was observed after doxorubicin treatment (intraperitoneally at $3.2 \mathrm{mg} / \mathrm{kg}$ ). In particular, in mice treated with doxorubicin, a significantly higher accumulation of ${ }^{99 \mathrm{~m}} \mathrm{Tc}$-pertechnetate was observed in Ad-hNIS-infected ARO xenografts than that in wild-type ARO xenografts or in nontreated Ad-hNISinfected ARO xenografts (Fig. 7B; $* P<0.05$ ). In addition, a significantly higher photon efflux was observed in AdLuc-infected ARO xenografts than in wild-type ARO xenografts or in nontreated Ad-Luc-infected ARO xenografts (Fig. 7D; $* P<0.05$ ).

\section{DISCUSSION}

Reduced iodine uptake in anaplastic and poorly differentiated thyroid cancers is caused by a reduction in NIS activity, and this hinders radioiodine therapy. Much effort has been made to transfer the NIS gene into various cancer and anaplastic thyroid cancer cells $(9,10,17-20)$. However, the rapid washout and poor retention of radionuclide becomes problematic (9), and transgene expression may be reduced with time after transfer $(21,22)$. Although many studies have been undertaken to enhance transfer rates or transgene effects $(12,23-25)$, the effect of doxorubicin on transduced cells has been examined only rarely. Doxorubicin is one of the most powerful cancer treatment reagents. Besides the doxorubicin effect on NF- $\kappa \mathrm{B}$ response element of CMV promoter, the combination of doxorubicin and radioiodine could be a more useful strategy for cancer therapy. 


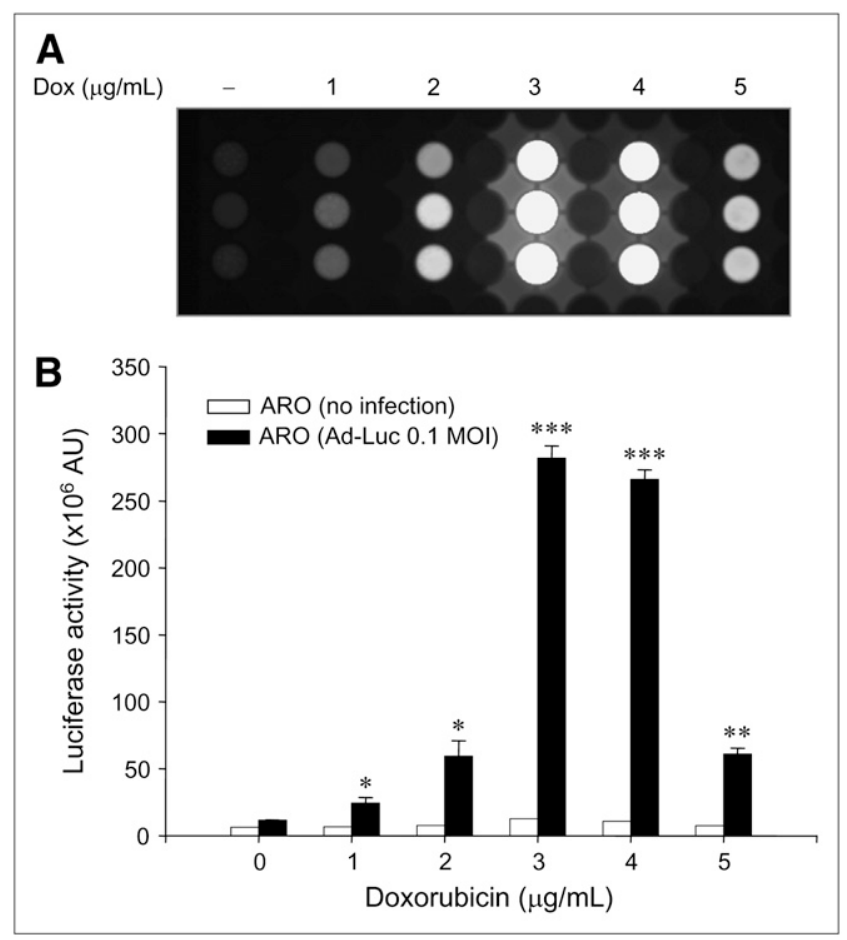

FIGURE 4. Dose-dependent upregulation of bioluminescence by doxorubicin (Dox) in Ad-Luc-transduced ARO cells. (A) In vitro bioluminescent images dependent on doxorubicin concentrations in Ad-Luc-transduced ARO cells. Bioluminescent images were acquired as described in Figure 3 legend. (B) Dose-dependent upregulation of bioluminescence by doxorubicin in Ad-Luc-transduced ARO cells. Ad-Luc-transduced ARO cells also showed peak bioluminescence at a doxorubicin concentration of $3 \mu \mathrm{g} / \mathrm{mL}$. Results are mean \pm SD of 3 independent experiments performed in triplicate $\left({ }^{\star} P<0.05\right.$; ${ }^{* *} P<$ $0.005 ;{ }^{\star \star \star} P<0.001$ vs. nontreated cells infected with Ad-Luc). $\mathrm{AU}=$ arbitrary units.

In the present study, we observed that doxorubicin enhanced transgene expression under the control of the CMV promoter in vitro and in vivo. When ARO-hNIS cells were treated with doxorubicin, iodide uptake significantly increased up to 21.9-fold and, when mice bearing different types of tumors were treated with doxorubicin, significantly higher iodide uptake or bioluminescence was observed in Ad-hNIS- or Ad-Luc-infected ARO xenografts, respectively, than in wild-type ARO xenografts or in nontreated Ad-hNIS or Ad-Luc-infected ARO xenografts. RT-PCR analysis also suggested that this increased transgene expression is the result of increased transgene mRNA production.

In our study, transfected and transduced ARO cells showed maximal transgene expressions and activities at a doxorubicin concentration of $3 \mu \mathrm{g} / \mathrm{mL}$; further increases in doxorubicin reduced, rather than enhanced, transgene expression (Fig. 1B). Doxorubicin exerts its cytotoxicity by inducing DNA strand breaks by interacting with topoisomerase II $(26,27)$, and this effect of doxorubicin can induce cell cycle arrest or apoptosis. As shown in Figure 1A inset,
ARO cells maintained viability even at a doxorubicin concentration of $20 \mu \mathrm{g} / \mathrm{mL}$. We observed that the population of doxorubicin $(5 \mu \mathrm{g} / \mathrm{mL})$-treated ARO cells remained constant for $48 \mathrm{~h}$ (data not shown). These results suggest that the transcription of transgene was abruptly inactivated by the stalling of RNA polymerase II complexes at doxorubicin concentrations exceeding $3 \mu \mathrm{g} / \mathrm{mL}$ in ARO-hNIS and ARO-Luc cells under cell cycle arrest by doxorubicin treatment (28). Actually, in cell cycle analysis according to doxorubicin concentration, transient $\mathrm{G}_{2} / \mathrm{M}$ arrest occurred up to $2 \mu \mathrm{g} / \mathrm{mL}$, and $\mathrm{G}_{1}$ arrest progressed with concentrations of $3 \mu \mathrm{g} / \mathrm{mL}$ or higher. Our data are concordant with the demonstration of O'Loughlin et al. (29) in which transient $\mathrm{G}_{2} / \mathrm{M}$ arrest and subsequent progression into $G_{1}$ occurred dependent on doxorubicin exposure time in drug-resistant carcinoma cells.

When ${ }^{125}$ I uptake was measured in doxorubicin-treated ARO cells versus nontreated cells, no significant difference was observed. This result suggests that doxorubicin does not reactivate the silenced endogenous NIS gene but, rather, it induces transgene activation under the control of the CMV promoter. This effect of doxorubicin was also verified in ARO cells transduced with adenoviral vectors, including the CMV promoter.

Anthracycline drugs, such as doxorubicin, are known to be able to induce NF- $\mathrm{BB}$ activation (13), which results from the phosphorylation-induced degradation of its inhibitory protein, I $\mathrm{B} \alpha$, by proteosome $(30,31)$. It is generally accepted that the activation of the NF- $\kappa \mathrm{B}$ pathway in cancer cells represents an antiapoptotic mechanism $(32,33)$. Eventually, the activation of this pathway can make cancer cells resistant to chemotherapy and radiotherapy. In the present study, we found that doxorubicin stimulated the activation of NF- $\mathrm{KB}$ and its binding to the response element localized in the CMV promoter region and induced transgene expression, as was shown by the degradation of IкB $\alpha$ by Western blotting and NF- $\kappa \mathrm{B}$ binding by EMSA. In this study, the NF- $\kappa$ B pathway activated by doxorubicin induced NIS gene expression, resulting in the accumulation of therapeutic radioiodine. This finding indicates that doxorubicin pretreatment before radioiodine gene therapy may be effective for treating cancers that are resistant to conventional chemotherapy or radiotherapy.

However, we do not believe that this response of transgene expression is limited only to doxorubicin because it has been reported that most anticancer drugs, as DNAdamaging agents, activate the NF- $\mathrm{B}$ pathway. In our study, it was shown that the CMV promoter containing the NF- $\mathrm{KB}$ response element in its enhancer region was triggered by NF- $\mathrm{B}$ pathway activation as a result of doxorubicin treatment. Therefore, when other promoters have the NF-кB response element, these promoters can be activated by doxorubicin.

Our study shows that doxorubicin significantly enhances transgene expression under the control of a CMV promoter both in vitro and in vivo. In addition, we demonstrate that 
A

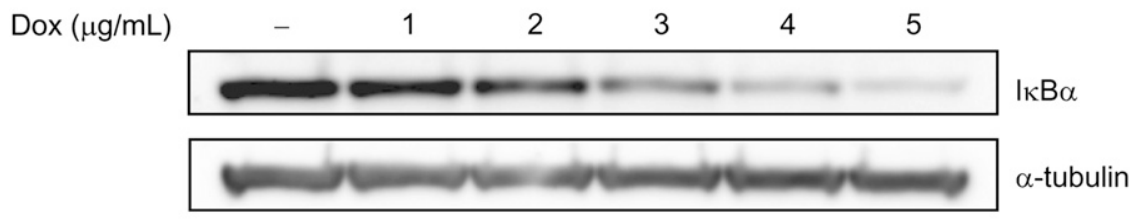

B

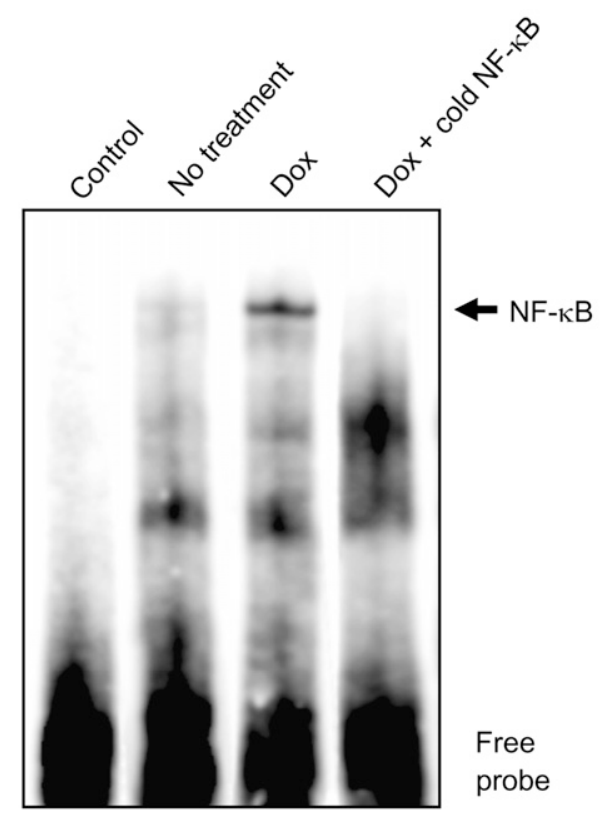

FIGURE 5. Influence of NF-кB activity on CMV promoter. (A) $I_{\kappa} \mathrm{B} \alpha$ degradation induced by doxorubicin (Dox). Immunodetection experiments on cytoplasmic extracts of ARO-hNIS cells treated with $0,1,2,3,4$, or $5 \mu \mathrm{g} / \mathrm{mL}$ of doxorubicin showed significant dose-dependent decreases in $\mathrm{I}_{\kappa} \mathrm{B} \alpha$ protein. (B) NF- $\mathrm{kB}$ binding activity induced by doxorubicin in ARO-hNIS cells. An increase in NF-kB binding to biotin-labeled oligonucleotide was observed after $24 \mathrm{~h}$ of doxorubicin treatment $(3 \mu \mathrm{g} / \mathrm{mL})$. this enhancement is mediated by the activation of NF- $\mathrm{BB}$. Moreover, because the CMV promoter has cis-regulatory elements recognized by various transcription factors-such as AP-1 (34), CREB (35), retinoic acid nuclear receptors (RARs) (36), and NF-кB (37)-further studies of other factors and combination treatments are required to help elucidate the reasons for improved transgene activity. Further experiments evaluating a prolonged accumulation of radionuclide and the tumorcidal effect of this improved method are also needed. Nevertheless, our results provide a useful strategy for gene therapy in the treatment of cancers in general.

\section{CONCLUSION}

We found that transgene expression driven by the CMV promoter was enhanced in ARO cells in vitro and in a mouse model by doxorubicin. Moreover, we determined that this enhancement was mediated by the activation of $\mathrm{NF}-\kappa \mathrm{B}$ in the CMV promoter. These findings indicate that

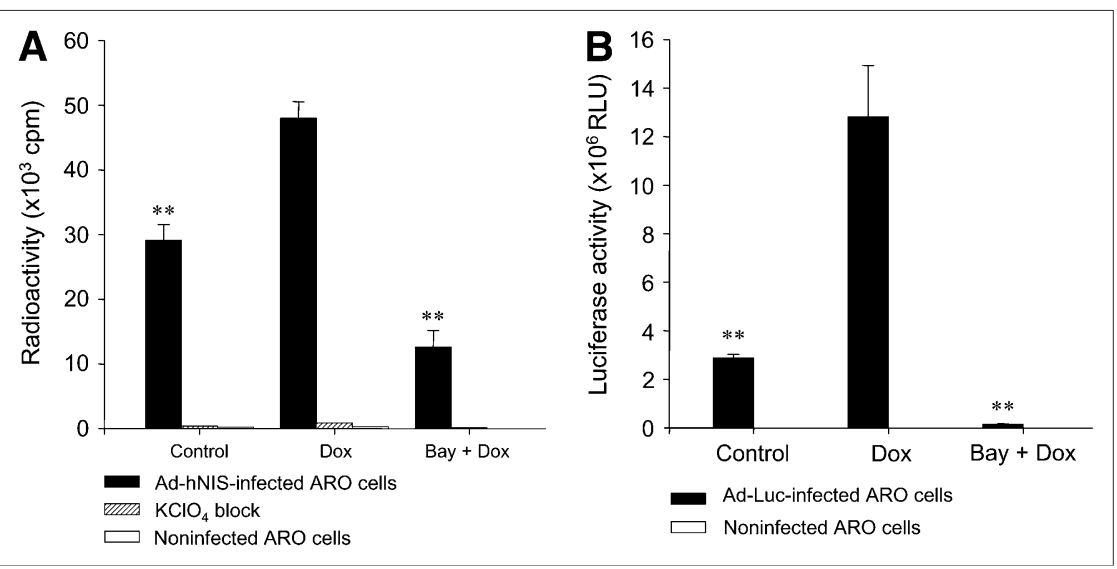

FIGURE 6. Effect of NF-кB pathway inhibitors on doxorubicin (Dox)-induced transgene expression in transduced ARO cells. (A) Cells infected with AdhNIS were pretreated with $10 \mu \mathrm{M}$ Bay 11-7082 for $1 \mathrm{~h}$ and then incubated with or without doxorubicin (3 $\mu \mathrm{g} / \mathrm{mL}$ ) for $24 \mathrm{~h}$. To confirm the function of hNIS, potassium perchlorate was used as an inhibitor. Cells were analyzed for ${ }^{125}$ | uptake. (B) Cells infected with Ad-Luc were pretreated with $10 \mu \mathrm{M}$ Bay 117082 for $1 \mathrm{~h}$ and then incubated with or without doxorubicin $(3 \mu \mathrm{g} / \mathrm{mL})$ for $24 \mathrm{~h}$ and analyzed for bioluminescence. Data are mean $\pm S D$ of experiments performed in quadruplicate $\left({ }^{\star \star} P<0.005\right.$ vs. doxorubicin-treated cells infected with Ad-hNIS (A), and doxorubicin-treated cells infected with Ad-Luc (B)). RLU $=$ relative light unit. 


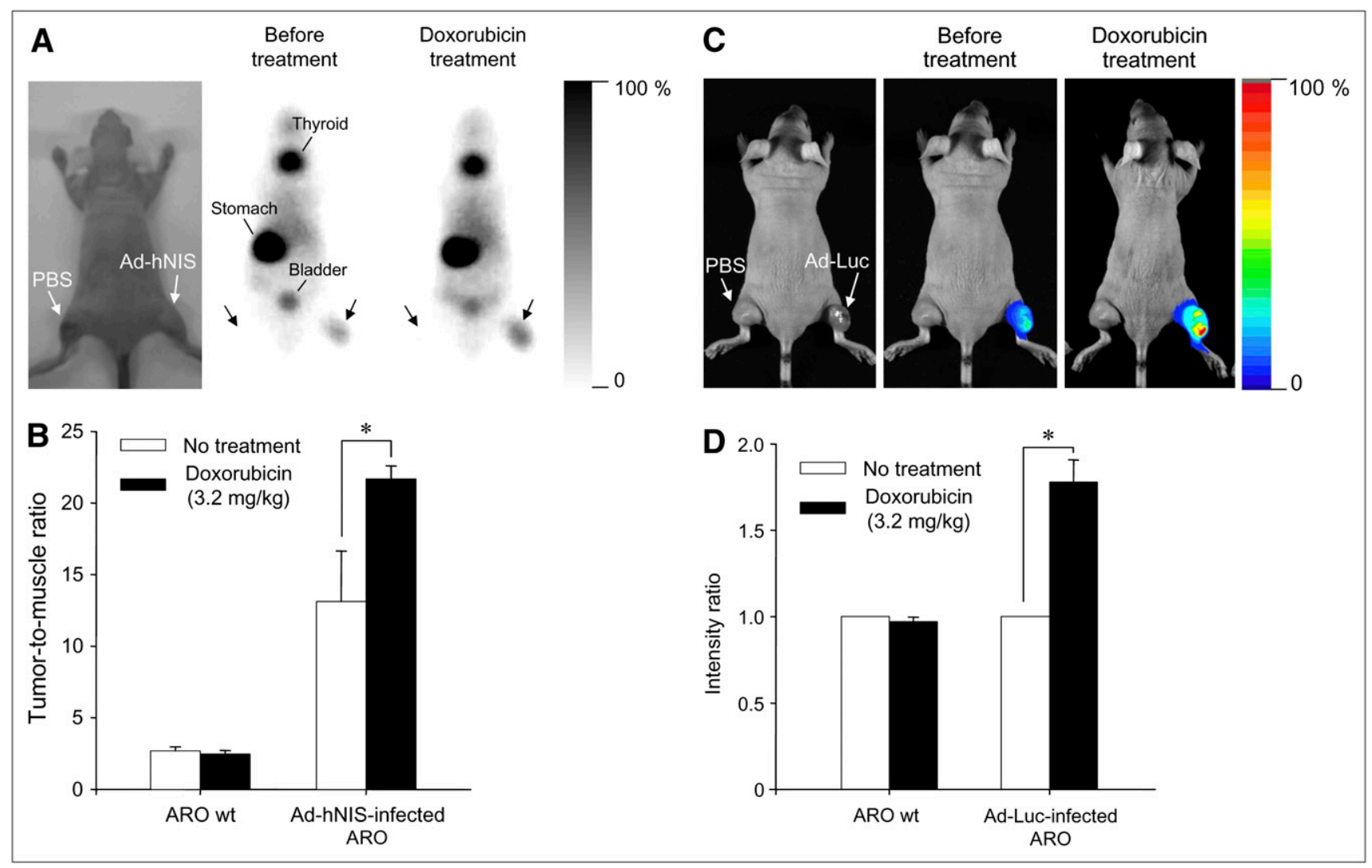

FIGURE 7. In vivo monitoring of transgene expression enhancement by doxorubicin using scintigraphic and bioluminescent imaging. (A) Scintigraphic imaging. Injection of 99mTc-pertechnetate and $\gamma$-camera imaging visualized hNIS gene expression enhancement by doxorubicin in Ad-hNIS-infected ARO tumor xenografts. (B) Tumor-to-muscle radioactivity ratio. Significant differences were observed before and after doxorubicin treatment ( $\left.{ }^{\star} P<0.05\right)$. Data are expressed as mean $\pm \mathrm{SD}(n=4)$. (C) Bioluminescent imaging. Injection of luciferin and acquisition of bioluminescent images showed luciferase gene expression enhancement by doxorubicin in Ad-Luc infected ARO tumor xenografts. (D) Bioluminescence intensity ratio. Significant differences were observed before and after doxorubicin treatment ( $\left.{ }^{\star} P<0.05\right)$. Data are expressed as mean \pm SD $(n=6)$. wt $=$ wild-type.

doxorubicin might be used as an adjuvant to radioiodine therapy by NIS gene transfer in anaplastic thyroid carcinoma. Further study in various cancers could provide a useful strategy for cancer gene therapy.

\section{ACKNOWLEDGMENTS}

This work was supported in part by grant 03-2004-013-0 from the SNUH Research Fund and the Korean Science \& Engineering Foundation at the Tumor Immunity Medical Research Center at Seoul National University College of Medicine and by the BK21 Project for Medicine, Dentistry, and Pharmacy (2006).

\section{REFERENCES}

1. Fischer U, Steffens S, Frank S, Rainov NG, Schulze-Osthoff K, Kramm CM. Mechanisms of thymidine kinase/ganciclovir and cytosine deaminase/5-fluorocytosine suicide gene therapy-induced cell death in glioma cells. Oncogene. 2005;24:1231-1243.

2. Li Z, Shanmugam N, Katayose D, et al. Enzyme/prodrug gene therapy approach for breast cancer using a recombinant adenovirus expressing Escherichia coli cytosine deaminase. Cancer Gene Ther. 1997;4:113-117.

3. Shen Y, Nemunaitis J. Herpes simplex virus 1 (HSV-1) for cancer treatment. Cancer Gene Ther. 2006;13:975-992.
4. Buchsbaum DJ, Chaudhuri TR, Zinn KR. Radiotargeted gene therapy. J Nucl Med. 2005;46(suppl 1):179S-186S.

5. Spitzweg C, O'Connor MK, Bergert ER, Tindall DJ, Young CY, Morris JC. Treatment of prostate cancer by radioiodine therapy after tissue-specific expression of the sodium iodide symporter. Cancer Res. 2000;60:6526-6530.

6. Haberkorn U, Henze M, Altmann A, et al. Transfer of the human NaI symporter gene enhances iodide uptake in hepatoma cells. J Nucl Med. 2001;42:317-325.

7. Cho JY. A transporter gene (sodium iodide symporter) for dual purposes in gene therapy: imaging and therapy. Curr Gene Ther. 2002;2:393-402.

8. Smanik PA, Liu Q, Furminger TL, et al. Cloning of the human sodium lodide symporter. Biochem Biophys Res Commun. 1996;226:339-345.

9. Chung JK. Sodium iodide symporter: its role in nuclear medicine. J Nucl Med. 2002;43:1188-1200.

10. Smit JW, Shroder-van der Elst JP, Karperien M, et al. Reestablishment of in vitro and in vivo iodide uptake by transfection of the human sodium iodide symporter (hNIS) in a hNIS defective human thyroid carcinoma cell line. Thyroid. 2000; 10:939-943.

11. Lee YJ, Chung JK, Shin JH, et al. In vitro and in vivo properties of a human anaplastic thyroid carcinoma cell line transfected with the sodium iodide symporter gene. Thyroid. 2004;14:889-895.

12. Vereecque R, Saudemont A, Wickham TJ, et al. Gamma-irradiation enhances transgene expression in leukemic cells. Gene Ther. 2003;10:227-233.

13. Das KC, White CW. Activation of NF-кB by antineoplastic agents: role of protein kinase C. J Biol Chem. 1997;272:14914-14920.

14. Sambucetti LC, Cherrington JM, Wilkinson GW, Mocarski ES. NF-к B activation of the cytomegalovirus enhancer is mediated by a viral transactivator and by T cell stimulation. EMBO J. 1989;8:4251-4258.

15. Kim KI, Chung JK, Kang JH, et al. Visualization of endogenous p53-mediated transcription in vivo using sodium iodide symporter. Clin Cancer Res. 2005;11:123-128. 
16. Chen L, Altmann A, Mier W, et al. Radioiodine therapy of hepatoma using targeted transfer of the human sodium/iodide symporter gene. J Nucl Med. 2006; 47:854-862.

17. Shimura H, Haraguchi K, Miyazaki A, Endo T, Onaya T. Iodide uptake and experimental ${ }^{131} \mathrm{I}$ therapy in transplanted undifferentiated thyroid cancer cells expressing the $\mathrm{Na}^{+} / \mathrm{I}^{-}$symporter gene. Endocrinology. 1997;138:4493-4496.

18. Mandell RB, Mandell LZ, Link CJ Jr. Radioisotope concentrator gene therapy using the sodium/iodide symporter gene. Cancer Res. 1999;59:661-668.

19. Min JJ, Chung JK, Lee YJ, et al. In vitro and in vivo characteristics of a human colon cancer cell line, SNU-C5N, expressing sodium-iodide symporter. $\mathrm{Nucl}$ Med Biol. 2002;29:537-545.

20. Schipper ML, Weber A, Behe M, et al. Radioiodide treatment after sodium iodide symporter gene transfer is a highly effective therapy in neuroendocrine tumor cells. Cancer Res. 2003;63:1333-1338.

21. DeMatteo RP, Yeh H, Friscia M, et al. Cellular immunity delimits adenoviral gene therapy strategies for the treatment of neoplastic diseases. Ann Surg Oncol. 1999;6:88-94.

22. Qin L, Ding Y, Pahud DR, Chang E, Imperiale MJ, Bromberg JS. Promoter attenuation in gene therapy: interferon-gamma and tumor necrosis factor-alpha inhibit transgene expression. Hum Gene Ther. 1997;8:2019-2029.

23. Nicklin SA, Wu E, Nemerow GR, Baker AH. The influence of adenovirus fiber structure and function on vector development for gene therapy. Mol Ther. 2005;12: 384-393.

24. Mastakov MY, Baer K, Xu R, Fitzsimons H, During MJ. Combined injection of rAAV with mannitol enhances gene expression in the rat brain. Mol Ther. 2001;3: 225-232.

25. Philippe S, Sarkis C, Barkats $M$, et al. Lentiviral vectors with a defective integrase allow efficient and sustained transgene expression in vitro and in vivo. Proc Natl Acad Sci USA. 2006;103:17684-17689.

26. Cummings J, Anderson L, Willmott N, Smyth JF. The molecular pharmacology of doxorubicin in vivo. Eur J Cancer. 1991;27:532-535.
27. Tewey KM, Rowe TC, Yang L, Halligan BD, Liu LF. Adriamycin-induced DNA damage mediated by mammalian DNA topoisomerase II. Science. 1984;226: 466-468.

28. Bregman DB, Pestell RG, Kidd VJ. Cell cycle regulation and RNA polymerase II. Front Biosci. 2000;5:D244-D257.

29. O'Loughlin C, Heenan M, Coyle S, Clynes M. Altered cell cycle response of drug-resistant lung carcinoma cells to doxorubicin. Eur J Cancer. 2000;36:11491160 .

30. Brown K, Gerstberger S, Carlson L, Franzoso G, Siebenlist U. Control of I kappa B-alpha proteolysis by site-specific, signal-induced phosphorylation. Science. 1995;267:1485-1488.

31. Karin M, Ben-Neriah Y. Phosphorylation meets ubiquitination: the control of NF-[kappa]B activity. Annu Rev Immunol. 2000;18:621-663.

32. Magne N, Toillon RA, Bottero V, et al. NF-kappaB modulation and ionizing radiation: mechanisms and future directions for cancer treatment. Cancer Lett. 2006;231:158-168.

33. Habraken Y, Piette J. NF-kappaB activation by double-strand breaks. Biochem Pharmacol. 2006;72:1132-1141.

34. Wade EJ, Klucher KM, Spector DH. An AP-1 binding site is the predominant cis-acting regulatory element in the 1.2-kilobase early RNA promoter of human cytomegalovirus. J Virol. 1992;66:2407-2417.

35. Rideg K, Hirka G, Prakash K, et al. DNA-binding proteins that interact with the 19-base pair (CRE-like) element from the HCMV major immediate early promoter in differentiating human embryonal carcinoma cells. Differentiation. 1994; 56:119-129.

36. Ghazal P, DeMattei C, Giulietti E, Kliewer SA, Umesono K, Evans RM. Retinoic acid receptors initiate induction of the cytomegalovirus enhancer in embryonal cells. Proc Natl Acad Sci USA. 1992;89:7630-7634.

37. Loser P, Jennings GS, Strauss M, Sandig V. Reactivation of the previously silenced cytomegalovirus major immediate-early promoter in the mouse liver: involvement of NFkappaB. J Virol. 1998;72:180-190. 